\title{
The Importance of a Business Plan when Planning a Lexicographical Project
}

\author{
Mariëtta Alberts, National Language Service, Department of Arts, Culture, \\ Science and Technology, Pretoria, Republic of South Africa
}

\begin{abstract}
This paper deals with the importance of a business plan when planning a lexicographical project. A business plan is an aspect of a lexicographical process most lexicographers would like to ignore. It is, however, an important step towards the establishment of a dictionary project. The compilation of a dictionary is a time-consuming process and a costly business, and proper planning is of the utmost importance, whether a dictionary project is undertaken by an individual or by a team of lexicographers. Therefore a business plan is the ideal tool for proper planning before embarking on a lexicographical project. It also gives stakeholders an indication of the scope of the envisaged lexicographical project. Financiers require a business plan to authorise the financing of a project, and this also applies to a lexicographical project. This paper deals with the importance of and reasons for a business plan. It also covers aspects such as drawing up a business plan as well as its contextual requirements.
\end{abstract}

Keywords: ACTION PLAN, BUSINESS PLAN, COLLABORATORS, CRITICAL SUCCESS FACTOR, EMPIRICAL SURVEY, END USER, FINANCIER, GOAL, HUMAN RESOURCES, KEY SERVICE, KEY UNCERTAINTY, KNOWLEDGE TRANSFER, LEXICOGRAPHICAL PRACTICE, LEXICOGRAPHY UNIT, MISSION, NEEDS ASSESSMENT, OBJECTIVE, OPPORTUNITY, ORGANISATIONAL STRUCTURE, RISK, SITUATION ANALYSIS, STAKEHOLDER, STRATEGY, VISION

Opsomming: Die belangrikheid van 'n sakeplan wanneer 'n leksikografiese projek beplan word. Hierdie artikel handel oor die belangrikheid van 'n sakeplan by die beplanning van ' $n$ leksikografieprojek. ' $n$ Sakeplan is ' $n$ aspek van die leksikografieproses wat liefs deur die meeste leksikograwe geignoreer sou wou word. Dit is egter ' $n$ belangrike stap in die totstandbrenging van ' $n$ leksikografieprojek. Die saamstel van ' $n$ woordeboek is ' $n$ tydrowende proses en duur saak en behoorlike beplanning is van die uiterste belang of die woordeboekprojek deur ' $n$ individu of deur ' $n$ span leksikograwe aangepak word. Derhalwe is ' $n$ sakeplan ' $n$ uitstekende hulpmiddel om behoorlike beplanning te doen voordat daar met 'n leksikografieprojek begin word. Dit gee aan belanghebbendes ' $n$ aanduiding van die omvang van die beoogde leksikografiese projek. Finansiers vereis ' $n$ sakeplan om die finansiering van 'n projek goed te keur en dit geld ook

This paper was read at the Fourth International Conference of the African Association for Lexicography, held at the University of Pretoria, Pretoria, 5-6 July 1999. 
vir 'n leksikografieprojek. Hierdie artikel handel oor die waarde van en rede vir 'n sakeplan. Dit dek ook aspekte soos die opstel van 'n sakeplan, sowel as die inhoudelike vereistes daarvan.

Sleutelwoorde: AKSIEPLAN, BEHOEFTEBEPALING, BELANGHEBBENDE, DOEL, DOELWIT, EINDGEBRUIKER, EMPIRIESE ONDERSOEK, FINANSIER, GELEENTHEID, INLIGTINGOORDRAG, KRITIEKE SUKSESFAKTOR, LEKSIKOGRAFIE-EENHEID, LEKSIKOGRAFIEPRAKTYK, MEDEWERKERS, MENSLIKE HULPBRON, MISSIE, ORGANISASIESTRUKTUUR, RISIKO, SAKEPLAN; SITUASIEANALISE, SLEUTELDIENS, SLEUTELVERANDERLIKE, STRATEGIE, VISIE

\section{Introduction}

A dictionary is a linguistic tool used for the development and preservation of languages. It may be regarded as an indispensable tool in the process of knowledge transfer at the targeted education or training levels and for promoting effective communication.

Dictionaries develop as a result of the specific language needs of language communities. The compilation of a dictionary can be a private enterprise or it can be state funded. The compilation of a dictionary is a time-consuming and costly process.

It is usually also the culmination of the professional contributions of a vast number of expert collaborators and (in the case of terminology) subject-field specialists, and the dedication and hard work of a number of language practitioners over a long period of time.

At present the lexicographical practice in South Africa is fragmented, since there are many established lexicographical interests financed either privately or by the Government. Different components originated from particular historical, cultural and organisational conditions, and consequently have a right to exist and are maintained for particular reasons.

All the stakeholders in the lexicographical practice, be it private lexicographers, publishers, language bureaux, academics, etc., need to plan their projects carefully. Many lexicographers decide to compile dictionaries based either on a feeling what they think to be a marketable product or on an idea which they believe to be viable. It is, however, very important to check the facts and to examine the viability of the idea by means of a needs assessment before embarking on the project.

To compile effective dictionaries it is important to undertake studies to assess the needs of dictionary users. The results of a needs assessment study will provide some of the required indications as to the viability of an envisaged project (Alberts 1992: 1). According to Wiegand (1987: 178, 179) an empirical study on dictionary usage and the needs of dictionary users will enhance the usability of envisaged dictionaries. Identified needs will lead to effective dictionaries and will therefore contribute towards eliminating obstacles in communication (Alberts 1992: 1). 
Given the above-mentioned facts and taking into account the expenses in time and money in establishing the relevant database for the compilation of a given dictionary, it is vital to plan a lexicographical project. The entire effort may be regarded a fruitless expenditure if in the end it transpires that the dictionary cannot be published due to certain constraints.

A business plan is the ideal tool for proper planning before embarking on a lexicographic project - whether done by an individual, a group of lexicographers, or a lexicographic unit. It provides the lexicographer with the opportunity to take a realistic, detached look at the process in its entirety. It also assists him/her to identify areas of strength and weakness; pinpoint needs and details one might overlook; and aids the lexicographer in determining how he/she can best achieve his/her goal to serve the target user group.

Perhaps the best way in which to show why a business plan is important, is to consider answers to questions such as:

- What exactly is a business plan?

- Why do you need one?

- When do you prepare one?

- How do you prepare one?

- Who has to prepare it?

\section{What is a business plan?}

A business plan is a detailed action programme outlining every conceivable aspect of your proposed lexicographical venture. It is a comprehensive, selfexplanatory plan of

\section{- what you intend doing, \\ - how you intend doing it, \\ - when you intend doing it, \\ - where you intend doing it, and \\ - why you believe your idea is viable.}

It is in essence a structured guideline to achieving your goals (cf. Morobe 1999: 42).

The main purpose of a business plan is to demonstrate to the stakeholders that proper advance planning has been done. There can be no fixed format for a business plan. The format adopted depends on the nature of the endeavour, the nature of the institution, the needs of the stakeholders and target users, as well as other factors, e.g. regulatory requirements that apply to some institutions. The exact format is therefore dependent on the above purpose, taking into account the factors mentioned. The guidelines given should be adopted to suit the lexicographical project's unique circumstances. 


\section{Why do you need a business plan?}

There are a number of good reasons for preparing a business plan. Amongst others, the following can be cited:

- sourcing finance: financial institutions require a business plan to authorise finance;

- feasibility: because a business plan requires the lexicographer to look at every aspect of the lexicographical process, it enables him/her to assess the feasibility of the project proposal;

- sourcing new ideas: by examining all the different aspects of the lexicographical process, other more profitable ideas may be discovered which may also be exploited;

- problems: a business plan enables the lexicographer to take cognisance of envisaged problems and to try to deal with them before engaging in the project;

- staff and technological needs: it helps to determine how many lexicographers or support personnel might be needed and to identify the need for technological assistance in the form of computer equipment (e.g. hardware), programs (e.g. software), etc.;

- managing the lexicographical process: it also acts as a strategic plan for the governing body by setting out a plan of action and estimating financial requirements which can later be used to manage the lexicographical process.

There is an old saying: "If you don't know where you are going, any road will take you there." In crafting sensible lexicographical strategies, you should know where you may end up, and have a good map to get there. A lexicographical project is at best a tiring adventure demanding a lot of time and patience. A business plan therefore serves as a kind of road map: as every traveller knows, a journey is a lot less risky when you have direction.

\section{When do you need a business plan?}

A business plan is the lexicographer's principal means of communicating his/her ideas to providers of capital and to partners or publishers to invest time and money in the lexicographical project. It often becomes the basis of an application when seeking financing for the project (cf. Morobe 1999: 42).

\section{Who has to prepare the business plan?}

The person with the executive responsibility in the lexicographical process (the project manager) should prepare the business plan. The project manager 
should be assisted with this task by a project team (i.e. the lexicographer(s) who will carry out the business plan). The financial side (e.g. balance sheet, income statement and cash flow forecasts) may require the services of an accountant. However, the essence of the plan should be drawn up by the project manager and the project team.

\section{The importance of a business plan}

According to Morobe (1999: 42) the importance of planning cannot be overemphasised. To maximise the effectiveness of business planning, it should be preceded by strategic planning related to the needs assessment. The business plan need not contain full details of the outcome of strategic planning, only enough to enable the reader to understand the business plan properly.

During the preparatory stages of any prospective lexicographical project it is wise to spend more time than the lexicographers might deem necessary to formulate the the business plan. This is important for the following reasons:

- it ensures that the project team arrange their thoughts in a logical order;

- it assists the project team in identifying and formulating objectives;

- it helps the project team to develop strategies to meet those objectives;

- it helps them to provide a structure to the lexicographical project by defining activities and responsibilities;

- it forces the project team to simulate reality and anticipate pitfalls;

- it serves as a working action plan or guideline when the lexicographical project is up and running;

- it is an essential aid when applying for financial assistance or when marketing the envisaged end product to a potential publisher; and

- it builds team spirit within the project team.

\section{The business plan as a financial tool}

Lexicographers need a business plan to obtain financial assistance, and for this reason the business plan must provide information required by others to evaluate the envisaged lexicographical project. A thorough plan becomes a financing proposal that will meet the requirements of most investors, lenders or publishers.

There are various kinds of financiers which may be approached by a lexicographer. Private funds may, as a first option, be raised by tapping one's own (or the lexicography unit's own) financial resources. Other options may include raising money from trusts, banks or other financing houses. Funds or grants may also be obtained from sources such as government departments, or from a specific language body such as the Pan South African Language Board. Most 
financiers will only provide money if the business plan inspires confidence with regard to a secure and profitable future. One should bear in mind that financiers do not think about the envisaged lexicographical project in the way the project leader and project team do. They have not been researching the envisaged project for several months and are seeing the proposal on paper for the first time.

When lexicographers need a business plan, they already think about the funds required to start the venture. They not only need funds, but also face the frustration of being at the back of the line for conventional lending resources. Large lenders do not back non-profitable business such as dictionary projects, and lexicographers have neither the time nor the financial expertise to find the right sources or to package their project in a manner to persuade lenders to accommodate them. Whatever kind of lender the lexicographer finally finds, he/she will have to present a proper business plan.

\section{How do you prepare a business plan?}

A business plan should start off with a mission statement. This is a short, clear, precise statement of the reason for the lexicographical project. It is intended to focus the reader's mind sharply on the purpose of the project. The mission should be phrased in such a way that all employees (project leader, lexicographers, etc.) can continuously test if and how their activities contribute towards fulfilling the mission.

The business plan need not describe goals and strategies in detail. That belongs in the strategic plan. The compilers of the business plan may however wish to include abridged details in order to make the chosen organisational structure and objectives comprehensible.

A situational analysis will provide the reader with insight into the current situation that necessitates the compilation of the planned dictionary.

A brief description of the various organisational segments and the function of each should be given. The design of the organisational structure should be based on a strategic planning exercise. In such an exercise the project team determines what goals it should pursue to fulfil its mission. Then the team decides on the strategies it should adopt to achieve these goals. Having determined goals and strategies, it becomes possible to determine an organisational structure such as divisions or sections required to perform various tasks relating to the project as well as their interrelationships and functions.

Where appropriate, projections of key variables that were used to do the business planning should be given to clarify the rationale behind the business plan.

A good business plan covers the following key areas: people, opportunity, context, risk and reward. 


\subsection{People}

This aspect of the business plan refers to the men and women starting and running the lexicographical project as well as the outside parties providing information, key services or resources for it.

The project leader needs to ask him-/herself a number of questions regarding the people involved, and these include:

- Where are they from?

- What experience do they have directly relevant to the opportunity?

- What expertise, skills, knowledge and abilities do they have?

- How committed are they to this venture?

- How realistic are they about the venture's chances of success and the tribulations?

- Who are the end users: scholars, students, a subject community or the general public?

- Who are the stakeholders?

- Who are the collaborators?

\subsection{Opportunity}

This is a profile of the project itself, what it will produce and for whom (known as the users group), whether it can grow and how fast, what its economics are, and who and what stands in the way of success.

One needs to state the mission, vision and goal of the project. An analysis of the present situation and the critical factors influencing the project can be given, with an outline of the strategies envisaged to obtain the set goals. Key uncertainties should be mentioned. The organisational structure with an indication of the present or approved staff complement as well as an indication of an extended staff complement should be given. One should also mention the human resources plan in order to accommodate all aspects of the envisaged project.

Questions that need to be asked regarding the opportunity include:

- What is the mission, vision and goal of the project?

- What is the present situation that will influence the project?

- What are the strategies envisaged to obtain the set goals?

- What organisational structure is needed?

- What key variables are projected?

- What are the objectives of the project?

- What are the critical success factors?

- What key uncertainties can be identified?

- What action plans must be introduced?

- What are the milestones to be specified? 
- Will the human resources be able to conduct the project?

- Does the market actually allow you to make a profit from this lexicographical project?

- Who is the user group for the new lexicographical project?

- At how much will the product or service resulting from the product (e.g. telephone enquiring service) be priced?

- How much will it cost to produce and deliver the lexicographical product or service?

- How do you put a monetary value to the product and service?

- Does the user pay cash or on credit?

- Who are the current competitors?

The literature on business planning is inconsistent regarding the meanings assigned to the terms used in this paper. One often finds that terms such as "goals", "objectives" and "targets", for example, are used interchangeably. For the purpose of describing the required contents of a business plan, they are given specific meanings in this paper.

A goal is a description of a state of affairs towards which the project team strives. It should naturally be as specific as possible, but need not be fully quantified.

An objective on the other hand should be quantified as closely as possible.

Having determined a goal, further detailed analysis and planning are needed to arrive at objectives. In the process certain end goals have to be broken down into sets of supporting goals; objectives cannot be quantified unless broken down into subobjectives, etc. The first set of goals can cascade down through multiple tiers to a set of detailed objectives that have to be reached to ultimately achieve the goals. These objectives need to be clearly stated in the business plan.

The factors that are considered to be critical for the successful execution of the business plan should be stated. That will enable the outside agencies (financiers, publishers, etc.) to form a better impression of the support they should attempt to provide to ensure success.

Any key uncertainties which can seriously hamper the execution of the business plan should be stated.

Action plans associated with each objective should be given, stating important target dates and responsibilities. Under certain circumstances it is deemed necessary to organise the action needed to meet objectives into projects rather than simply giving an organisational segment the responsibility for meeting the objective. A project is normally initiated to meet a specific objective, after which it is closed. Unless they are negligible in scope and budget, 
projects should be described in the business plan. The objective, main action steps and budget should, among others be given.

The process of compiling a dictionary is a time-consuming exercise. Certain objectives may only be reached within years. For them the business plan should specify milestones with target dates which should be reached in the time-span covered in the business plan.

The business plan should state all sources of income and the amounts expected from each. Estimated expenditure, broken down into an appropriate list of items should also be included. Current and capital expenditure should be shown separately. A projected balance sheet for the end of the financial year should be given. A budgeted cash flow with estimated payments. for each month of the financial year should also be included in the business plan.

\subsection{Context}

This includes the big picture - the usual environment, interest rates, demographic trends, political influences, inflation, and the like - factors that inevitably change but cannot be controlled by the lexicographer.

Questions that may be asked include:

- How do the macro- and market environments relating to lexicography hinder or promote the venture?

- How will changes in the lexicographical environment impact on the venture?

- What can the project leader and project team do if the environment should become unfavourable?

\subsection{Risk and reward}

This refers to an assessment of everything that can go wrong and go right, and an outline of how the project team can respond.

- What is the risk and how will it be managed?

- What rewards will the project deliver and to whom, when and how much?

\section{Financial forecasts}

A comprehensive outline of the financial plan and strategy of the project is often the most difficult aspect for most lexicographers. The essence lies in converting operational activities into money. For this the lexicographer needs to compile an estimated balance sheet, income statements and cash flow statements. These figures will reflect the key drivers of the project's success or fail- 
ure. The figures will also highlight the break-even level and the point at which cash flow turns positive. The services of an accountant may be sought for this aspect - especially if it is a major lexicographical project undertaken by for instance a lexicographical unit.

\section{Conclusion}

The compilation of a dictionary is an economical activity. A dictionary project needs to adhere to the same basic business principles as any other business venture if it aims to be a viable business proposition. Institutions which are serious in rendering a constructive contribution to reconciliation and nation building in South Africa might aim to give financial support to different dictionary projects in South Africa. However, before financing any dictionary project they will need proof of proper planning and management of such projects. A business plan can provide such proof.

\section{Note}

Dr Mariëtta Alberts was responsible for the drafting of new legislation to establish national lexicographical (dictionary) units for all the official languages (1995-1996). The Bill was ratified in June 1996. The Draft Bill was later incorporated into the revised PANSALB Act as regulations concerning the establishment of national lexicographical units.

\section{Bibliography}

Alberts, Mariëtta. 1992. Behoeftebepaling in die leksikografie. Lexikos 2: 1-27.

Morobe, David. 1999. The importance of your business plan. People Dynamics 17(3): 42-44.

Wiegand, H.E. 1987. Zur handlungstheoretischen Grundlegung der Wörterbuchbenutzungsforschung. Kuťera, A., A. Rey, H.E. Wiegand and L. Zgusta (Eds.). 1987. International Annual for Lexicography: 178-227. Tübingen: Max Niemeyer. 